\title{
Empirical Evidences on Turkish Tourism-led Growth Experience in the Presence of a Structural Break
}

\author{
Yapısal Kırılımanın Varlığında Türkiye'nin Turizm Yanlı \\ Büyüme Tecrübesine Dair Ampirik Bulgular
}

\section{Dr. Lecturer Burcu Türkcan}

Başvuru Tarihi: 27.07.2015

Kabul Tarihi: 04.08.2017

\section{Introduction}

Recently, the importance of tourism in the economic growth process has been recognised widely in the literature, due to its contributions to the macroeconomic indicators such as balance of payments (BOP), production and employment. In this context, tourism-led growth (TLG) hypothesis has received a great deal of attention from both academicians and politicians. TLG hypothesis postulates that international tourism is the potential factor of economic growth process (Brida et al., 2008, p. 1). This hypothesis has its origins in export-led growth (ELG) model which is an economic model mostly applied by developing countries looking for a niche market for a certain type of export activity in the world economy. Governments in those countries subsidise industries producing particular export goods and hence expect to obtain resources to finance similar activities. ELG model has been analysed by McCombie \& Thirlwall (1994) who stated that increasing exports is the main tool to increase the economic growth rate without deteriorating $\mathrm{BOP}$.

TLG hypothesis plays an important role in ELG approach, since tourism is also an export activity that could maintain BOP and could obtain financial resources from foreign countries. Consequently, tourism is an important export industry which can provide necessary funds to finance the disequilibrium in BOP, increase the competitiveness of firms and hence contribute directly to the economic growth process (Nissan et al., 2011, p. 1568).
Anahtar Kelimeler: Turizm Yanlı Büyüme, Yapısal Kırılma, Zaman Serisi, Eşbütünleşme, Nedensellik

Dr. Lecturer Burcu Türkcan, Ege University Faculty of Economics and Administrative Sciences, burcu.turkcan@ege.edu.tr 
World Travel\&Tourism Council (2014b) has estimated that the proportion of tourism sector was approximately $\% 9.6$ of the World's GDP in 2014 . Hence the rising importance of TLG hypothesis has attracted an increasing amount of research efforts among many different countries. Most of the empirical studies in the literature prove that tourism is crucial for economic growth process and they suggest that TLG hypothesis is valid in numerous cases (Albaladejo et al., 2014; Brida et al., 2013; Hye\&Khan, 2013; Tang\&Tan, 2013; Arslanturk\&Atan, 2012; Srinivasan et al., 2012; Arslanturk et al., 2011; Husein\&Kara, 2011; Lionetti\&Gonzalez, 2011; Nissan et al., 2011; Belloumi, 2010; Brida et al., 2010; Katircioglu, 2010; Katircioglu, 2009b; Katircioglu, 2009c; Brida et al., 2008; Proenca\&Soukiazis, 2008; Sequeira\&Nunes, 2008; Parrilla et al., 2007; Cortes-Jimenez\&Pulina, 2006; Demiroz\&Ongan, 2005; Gunduz\&Hatemi-J., 2005; Kasman\&Kasman, 2004). However some of the studies state that the existence and the direction of causal relationship between tourism and economic growth depend on the country group and tourism indicator examined. In this context, Aslan (2014) shows that there is bidirectional causal relationship for economic growth and tourism development in Portugal, but unidirectional causality in Spain, Italy, Tunisia, Cyprus, Croatia, Bulgaria and Greece. Moreover, there is no causal relationship in Malta and Egypt. As another study, Tugcu (2014) states that European countries are better able to generate growth from tourism in the Mediterranean region. Furthermore, Caglayan et al. (2012) shows that there is bidirectional causality in Europe between tourism revenues and GDP. However, causality runs from tourism revenue to GDP in East Asia, South Asia and Ocenia. Moreover, there is no causal relation in Asia, Middle East and North Africa, Central Asia and Sub-Saharan Africa. Also there is unidirectional causality from GDP to tourism revenue in USA, Latin America\&Caribbean and the World. Lastly, Katircioglu (2009a) indicates that there is no validity of TLG hypothesis in Turkey. This great diversity in TLG research as well as real economic outcomes has produced important new knowledge and different perspectives about this phenomenon.

Researches on the economic impacts of tourism sector on GDP point out the critical importance of this sector in economic growth process in Turkey as well as in the World. The total contribution of tourism sector to Turkey's GDP has been estimated as TRY200.5 billion (12.4\% of GDP) by 2014 (WTTC, 2014a). Consequently, the analyses on tourism industry and TLG hypothesis are quite important for especially policy makers. In this context, the main purpose of this study is to analyse the validity of TLG hypothesis in Turkey for 1965 - 2013 period. Although there are some empirical studies in the literature analysing this issue for Turkey, this study's contributions to this literature are twofold. Firstly, the most recent data are used for this analysis and secondly, the structural break in the macroeconomic series is taken into account and relevant techniques are conducted for the first time in the literature of Turkish TLG experience. Although Yavuz (2006) realised the existence of structural breaks in tourism and GDP series in Turkey, this study only applied a unit root test for a structural break and causality test under such circumstances. Hence, our study is the first one which conducts a cointegration test with a structural break. In this context, after a brief introduction, the model and data used in this study are expressed. Then the methodology and empirical results are described in the next section. Lastly in the conclusions, interpretations of empirical results and policy implications are given.

\section{The Model and Data}

This study aims to examine the validity of TLG hypothesis for Turkey in the period of $1965-2013$. Drawing on the model of Balaguer \& Cantavella-Jor$\mathrm{da}$ (2002) the following model is used to follow this purpose:

$\mathrm{GDP}=\mathrm{f}($ Tourism Revenues, Foreign Exchange $)$

The model includes foreign exchange rates since numerous studies on TLG hypothesis -such as Belloumi et al.(2010), Brida et al. (2009), Gunduz \& Hatemi-J (2005) and Balaguer \& Cantavella-Jorda (2002)- suggest that the inclusion of this variable is quite important to overcome potential overlooked variable problem.

Tourism revenues are also included in the model by following the related literature. Actually different studies use different tourism indicators to analyse TLG hypothesis. For example, Caglayan et al. (2012), Arslanturk (2011), Husein \& Kara (2011), Belloumi (2010) and Gunduz \& Hatemi - J (2005) examine tourism revenues. However, Nissan et al. (2011) and 
Brida et al. (2009) examine tourism expenditures. Furthermore, Tang \& Abosedra (2014) and Katircioglu (2011) examine tourist arrivals as a tourism measure. However, since the most of the studies in the literature examine tourism revenues to detect TLG hypothesis, this variable has also been chosen as the tourism indicator in this study.

Moreover, data sets covering 1965 - 2013 period are used for the dependent and independent variables. GDP series was obtained through expenditure approach and measured in 1998 constant prices. Since the recent data on annual GDP is for 2013, period ends up in this year. GDP data were gathered from Turkish Statistical Institute. Moreover, tourism revenues, as one of the independent variables, were retrieved from Turkish Ministry of Culture and Tourism and Turkish Statistical Institute. Lastly, foreign exchange rates (Turkish lira value of the US dollar) were used as the other independent variable and yearly values were calculated by taking averages of daily real exchange rates. This data were retrieved from the Central Bank of the Republic of Turkey's Foreign Exchange Database. All three series are in logarithmic forms and hence the main model in this paper becomes:

$\log \mathrm{GDP}_{\mathrm{t}}=\beta_{0}+\beta_{1} \log \mathrm{TOUR}_{\mathrm{t}}+\beta_{2} \log \mathrm{FOREX}_{\mathrm{t}}+\mathrm{e}_{\mathrm{t}}$

In this model, GDP is gross domestic product; TOUR is tourism revenues and FOREX is real foreign exchange rates. Also, $\mathrm{e}_{\mathrm{t}}$ is error term and $\mathrm{t}$ in all variables denotes the time dimension of model.

\section{Methodology and Empirical Results}

\section{Unit Root Test with a Structural Break}

Stochastic processes forming series can sometimes be nonstationary and hence, such series cannot be analysed and evaluated by standard statistical theory. Stationarity is an important issue for regression analysis. If nonstationary series are used for econometric analyses, then artificial regression problem may occur and this may cause wrong econometric interpretations. Thus, there has been a consensus in the empirical literature to apply unit root tests on time series data. One of the most widely conducted unit root test in the literature is Augmented Dickey Fuller (ADF) Test (Said \& Dickey, 1984). In ADF Test, nonstationarity serves as the null hypothesis. Although this test has a very low power to express the true situations of series' stationarities in many cases like structural breaks, it's still widely used in the literature to have a prior opinion about series. Also, the results of ADF test are used in Toda-Yamamoto Causality Test which is applied in the presence of structural breaks. Hence, it is important to express firstly the results of $\mathrm{ADF}$ unit root tests of our series. Table 1 shows ADF test results for GDP, tourism revenues and foreign exchange rates series.

The results indicate that all three series have unit root problems in level. Consequently, they seem to be nonstationary. However, as it's stated before, ADF test and other traditional unit root tests are not good ways to interpret the series having structural breaks.

Table 1. Augmented Dickey-Fuller Test Results

\begin{tabular}{|c|c|}
\hline Series & ADF Statistic \\
\hline GDP & $-0.12(2)$ \\
\hline TOUR & $-2.35(2)$ \\
\hline FOREX & $-1.86(2)$ \\
\hline
\end{tabular}

Notes: MacKinnon (1991) critical values are used for ADF test. These critical values are:

-4.18 for $1 \%$ and -3.51 for $5 \%$. Values in parentheses are number of lags.

Structural breaks in time series may induce unit roots as shown by Perron(1989) and Hendry\&Neale(1991). Thus, classical unit root tests have low power when applied to series are of structural breaks (Campos et al., 1996: p. 188).
It's sure that since 1960s, Turkish economy has experienced a period in which some structural changes occurred. 1989 financial liberalization, 1994 economic downturn, 1998 Russian economic crisis, 2000 - 2001 banking sector crisis and 2007-2008 global 
financial crisis can be stated as main economic events have affected Turkish economy. Consequently, it's more appropriate to analyse Turkish macroeconomic series by unit root tests are of structural breaks (Yeldan\&Boratav, 2006, pp. 417 - 455).

One of the widely used unit root tests based on structural breaks is Zivot \& Andrews (1992). Zivot and Andrews criticised Perron (1989), since structural breakpoint was determined exogenously in that model. Hence they developed a unit root test which allows endogenously determined one structural break in the series. Zivot\&Andrews' unit root test is actually based on Perron(1989) and Perron (1997) models. Perron (1997), revised Perron(1989) and determined 3 basic models as follows:

Model A (Innovational Outlier Model):

$\mathrm{Y}_{\mathrm{t}}=\mu+\theta \mathrm{DU} \mathrm{t}_{\mathrm{t}}+\beta_{\mathrm{t}}+\delta \mathrm{D}\left(\mathrm{T}_{\mathrm{b}}\right)_{\mathrm{t}}+\alpha \mathrm{Y}_{\mathrm{t}-1}+\sum_{\mathrm{i}=1}^{\mathrm{k}} \lambda_{\mathrm{i}} \Delta \mathrm{Y}_{\mathrm{t}-\mathrm{i}}+\mathrm{e}_{\mathrm{t}}$

where $\mathrm{DU}_{\mathrm{t}}=1$ and $\mathrm{t}, \mathrm{T}_{\mathrm{B}} ; \mathrm{D}\left(\mathrm{T}_{\mathrm{b}}\right)_{\mathrm{t}}=1$ and $\mathrm{t}=\mathrm{T}_{\mathrm{B}}+1$

Model B (Additive Outlier Model): In this model change occurs rapidly and two steps are followed.

The first step: $\mathrm{Y}_{\mathrm{t}}=\mu+\beta \mathrm{t}+\delta \mathrm{DT}^{*}+\tilde{y}_{\mathrm{t}}$

where $\mathrm{DT}^{*}{ }_{\mathrm{t}}=1\left(\mathrm{t}, \mathrm{T}_{\mathrm{b}}\right)\left(\mathrm{t}-\mathrm{T}_{\mathrm{b}}\right) \cdot \tilde{\mathrm{y}}_{\mathrm{t}}$ values are obtained by applying Ordinary Least Squares (OLS) method to this equation.

The second step: $\tilde{y}_{\mathrm{t}}=\mathrm{ae}_{\mathrm{t}-1}+\sum_{\mathrm{i}=1}^{\mathrm{k}} \lambda_{\mathrm{i}} \Delta \mathrm{Y}_{\mathrm{t}-\mathrm{i}}+\mathrm{e}_{\mathrm{t}}$

Model C:

$$
\begin{aligned}
\mathrm{Y}_{\mathrm{t}}= & \mu+\theta D \mathrm{U}_{\mathrm{t}}+\beta_{\mathrm{t}}+\delta \mathrm{DT} \mathrm{T}_{\mathrm{t}}+\delta \mathrm{D}\left(\mathrm{T}_{\mathrm{b}}\right)_{\mathrm{t}}+ \\
& \alpha \mathrm{Y}_{\mathrm{t}-1}+\sum_{\mathrm{i}=1}^{\mathrm{k}} \lambda_{\mathrm{i}} \Delta \mathrm{Y}_{\mathrm{t}-\mathrm{i}}+\mathrm{e}_{\mathrm{t}}
\end{aligned}
$$

where $\mathrm{DT}_{\mathrm{t}}=1$ and $\mathrm{t}, \mathrm{T}_{\mathrm{b}}$.

In Model $\mathrm{A}, \mathrm{T}_{\mathrm{b}}$ denotes the time at which the change in the trend function occurs. This model allows only a change in the intercept and this change is assumed to occur gradually. In Model B, however, a change in the slope is allowed but this change is presumed to occur rapidly. In this model, break date $\mathrm{T}_{\mathrm{b}}$ and truncation lag parameter $\mathrm{k}$ are treated as unknown. Lastly, in Model C, both a change in the intercept and the slope are allowed at time $\mathrm{T}_{\mathrm{b}}$ (Perron, 1997, pp. 357 - 358).

However, Zivot and Andrews (1992) criticised Perron's these models on the point of exogenous breakpoint approach. Zivot and Andrews (1992) state that structural breakpoint is determined endogenously and also there is no time dummy variable $\mathrm{D}\left(\mathrm{T}_{\mathrm{b}}\right)$ in models. Hence, Zivot\&Andrews (1992) handled the following equations:

$$
\begin{aligned}
Y_{t}= & \mu^{A}+\theta^{A} D U_{t}(\lambda)+\beta^{A} t+\alpha^{A} Y_{t-1}+ \\
& \sum_{i=1}^{k} \lambda^{A} \Delta Y_{i}+e_{t} \\
Y_{t}= & \mu^{B}+\beta^{B} t+\delta^{B} D T_{t}(\lambda)+\alpha^{B} Y_{t-1}+ \\
& \sum_{i=1}^{k} \lambda^{B} \Delta Y_{i} \Delta e_{t-1}+e_{t} \\
Y_{t}= & \mu^{C}+\theta^{C} D U_{t}(\lambda)+\beta^{C} t+\delta^{C} D T^{*}(\lambda)+ \\
& \alpha^{C} Y_{t-1}+\sum_{i=1}^{k} \lambda_{i}^{C} \Delta Y_{t-1}+e_{t}
\end{aligned}
$$

Here, for $\mathrm{DU}_{\mathrm{t}}(\lambda)=1, \mathrm{t}>\mathrm{T} \lambda$ and for $\mathrm{DT}_{t}^{*}(\lambda)=\mathrm{t}-\mathrm{t} \lambda, \mathrm{t}>\mathrm{T} \lambda$

By using these models, table below shows the ZivotAndrews Unit Root Test Results for GDP, tourism revenues and foreign exchange time series of Turkey.

Table 2. Zivot-Andrews Unit Root Test Results
\begin{tabular}{|l|c|c|c|c|c|c|}
\hline \multirow{2}{*}{ Series } & \multicolumn{2}{|c|}{ Model A } & \multicolumn{2}{c|}{ Model B } & \multicolumn{2}{c|}{ Model C } \\
\cline { 2 - 7 } & min t-stat & Breakpoint & min t-stat & Breakpoint & min t-stat & Breakpoint \\
\hline GDP & $-1.53(0)$ & 2006 & $-4.11(0)$ & 2006 & $-7.68(0)$ & 2008 \\
\hline TOUR & $-4.70(2)$ & 1984 & $-3.42(2)$ & 1991 & $-3.90(2)$ & 1987 \\
\hline FOREX & $-2.98(2)$ & 1991 & $-3.11(2)$ & 2002 & $-3.21(2)$ & 1994 \\
\hline
\end{tabular}

Notes: Values in parentheses are number of lags determined by Akaike Information Criteria (AIC).

Following critical values are obtained from Zivot\&Andrews(1992):

$\begin{array}{llll}\text { Model A: } 1 \% & -5.34 & , 5 \% & -4.80 \\ \text { Model B: 1\% } & -4.93 & , 5 \% & -4.42 \\ \text { Model C: } 1 \% & -5.57 & , 5 \% & -5.08\end{array}$


Zivot-Andrews results indicate that there exist unit root problems with a structural break in all three series - except Model C for GDP. Also, structural break dates can be observed through breakpoint columns for each model. Results indicate more or less same dates for structural breaks. It seems that GDP has a structural break in 2006; tourism revenues have structural break between 1984 - 1991 and foreign exchange has structural break between 1991 - 2002 . Moreover, these results indicate that if a cointegration test will be applied, then it should take into account structural breaks.

\section{Cointegration Test with a Structural Break}

Cointegration tests have become an important tool of the empirical analyses on economic time series. Numerous tests have been introduced and widely conducted, but most of them rest on the assumption of unit root processes without structural breaks (Campos et al.,1996, pp. 213 - 214). These tests assume that coefficients in the cointegrated vector do not change with the time. However, Gregory \& Hansen (1996) developed a cointegration test which allows for an endogenously determined structural break, due to the fact that cointegrated vector coefficients actually change in the break date. Gregory \& Hansen Cointegration Test is mainly based on Zivot \& Andrews Unit Root Test and hence it includes 3 models allowing structural breaks in constant, in trend and in both constant and trend (Gregory \& Hansen, 1996: p. 103). In this study, Gregory\&Hansen Cointegration Test is conducted to detect the existence of the longrun cointegrated relationships between the examined variables.
However in order to be able to conduct this cointegration test, stationarity of series should be sustained by taking their differences. Following this purpose, first of all, first differences of series were taken and then Zivot - Andrews unit root test was applied for the differenced series. By taking the first difference of GDP, $\mathrm{t}$ statistic was founded as -7.52 for Model A; -8.20 for Model B and -8.12 for Model C. Also, t statistics for the first difference of TOUR series were -7.45 for Model A; -7.21 for Model B and -7.81 for Model C. Lastly, $\mathrm{t}$ statistics for first differenced FOREX series were -5.02 for Model A; -3.79 for Model B and -4.51 for Model C. These results show that FOREX series is not stationary at the first difference (critical values are given at the bottom of Table 2). However, as it is stated before, all the series should be stationary at the same level. Thus, second differences of the series should have been checked.

When the second difference of GDP series was taken, it's seen that $t$ statistic for Model A was -9.40; for Model B was -11.03 and for Model C was -11.94. Moreover, $t$ statistics for the second difference of TOUR series were, -7.29 for Model A; -7.01 for Model B and -7.69 for Model C. Lastly, $t$ statistics for the second difference of FOREX series were, -10.89 for Model A; -10.53 for Model B and -10.92 for Model C. All these results indicate that second differences of series are stationary (critical values are given in Table 2). Consequently, second differences of all three series can be used for the cointegration test and Table 3 below shows the Gregory\&Hansen Cointegration Test Results.

Table 3. Gregory - Hansen Cointegration Test Results

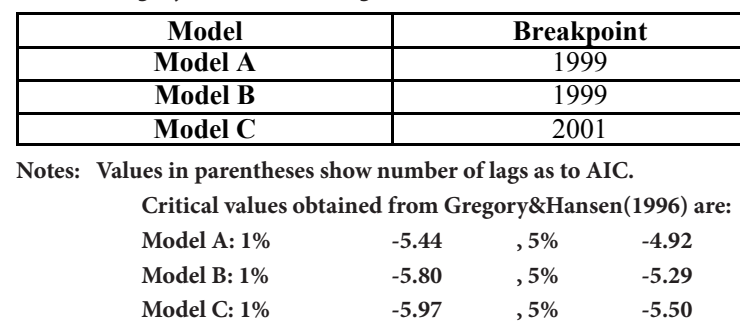


Since minimum ADF statistics of all models are greater than the critical values in absolute terms, results point out the long-term cointegrated relationships between GDP, tourism revenues and foreign exchange rates in Turkey for the period of $1965-2013$. Moreover, structural break occurs in 1999 as to both Model A and Model B. This date is quite important for Turkish economic history since it underlines the following year of Russian economic crisis which has affected directly Turkish economy. Also, Model C which points out the regime shift indicates a structural break in 2001. This date is also quite important for Turkish economy, since $2000-2001$ period witnessed the banking sector crisis which spreaded over all the sectors in the economy and a radical slowdown has been experienced in the national economy.

\section{Causality Test under Structural Break}

Although our cointegration results about tourism and GDP relationship are important to have some opinion about tourism-led growth story of Turkey, they only show that there exist long-run cointegrated relationships between variables examined. However, they do not explain anything about the direction of causality. Hence, there should be applied a causality test to analyse causal relationships between the variables. Since we have series having structural breaks, it would be inappropriate to apply traditional Granger causality test to find causality relationships. For this reason, Toda - Yamamoto Causality Test is conducted in this study.

Toda \& Yamamoto (1995) developed a simple method to test economic hypotheses expressed as restrictions on the parameters of Vector Autoregressive (VAR) models without pretesting for a unit root and a cointegrating rank. Their method is based on usual lag selection procedure to a possibly integrated or cointegrated VAR (as far as the order of integration of the process does not exceed the true lag length of the model). By choosing the lag length $k$, a $\left(k+d_{\text {max }}\right) t h$ -order VAR where $\mathrm{d}_{\text {max }}$ is the maximal order of integration, can be estimated (Toda \& Yamamoto, 1995:, pp. $245-246)$.

Hence in this study, firstly, order of integration is determined as $2(\mathrm{~m}=2)$, according to $\mathrm{ADF}$ results given at the beginning of this section. After deciding order of integration, the next step is determining the maximum lag length. Consequently, VAR Lag Order Selection Test is applied. The results are given below.

VAR lag order selection test results indicate that maximum lag length is $2\left(\mathrm{~d}_{\max }=2\right)$. Hence, Toda - Yamamoto Causality Test can be conducted with 2 order of integration and 2 maximum lag length. The following table shows test results.

Table 4. VAR Lag Order Selection Test Results

\begin{tabular}{|c|c|c|c|}
\hline Lag & LogL & LR & AIC \\
\hline $\mathbf{0}$ & 25.174 & - & -1.031 \\
\hline $\mathbf{1}$ & 39.722 & 26.388 & -1.289 \\
\hline $\mathbf{2}$ & 57.157 & $29.193^{*}$ & $-1.681^{*}$ \\
\hline $\mathbf{3}$ & 63.653 & 9.970 & -1.565 \\
\hline $\mathbf{4}$ & 73.704 & 14.024 & -1.614 \\
\hline
\end{tabular}

Notes: ${ }^{*}$ indicates lag order selected by the criterion

LR: sequential modified LR test statistic (each test at $5 \%$ level)

AIC: Akaike information criterion

Table 5. Toda-Yamamoto Causality Test Results

\begin{tabular}{|c|c|c|}
\hline Direction of Causality & $\chi^{2}-$ stat & Probability \\
\hline TOUR $\rightarrow$ GDP & 4.705 & 0.095 \\
\hline FOREX $\rightarrow$ GDP & 13.530 & 0.001 \\
\hline GDP $\rightarrow$ TOUR & 0.059 & 0.970 \\
\hline FOREX $\rightarrow$ TOUR & 1.051 & 0.591 \\
\hline GDP $\rightarrow$ FOREX & 0.605 & 0.738 \\
\hline TOUR $\rightarrow$ FOREX & 3.344 & 0.187 \\
\hline
\end{tabular}


According to Toda - Yamamoto Causality Test results, tourism revenues and foreign exchange rates seem to be the cause of GDP. However, the reverse is not true. Hence, there exist a unidirectional causality running from tourism revenues and foreign exchange rates through GDP.

\section{Conclusions}

This paper investigates the long-run and causal relationships of tourism revenues, foreign exchange rates and real GDP for Turkey by using empirical methods in the case of a structural break in time series. The methodologies employed in this paper allow overcoming econometric concerns that could appear in the application of traditional unit root, causality and cointegration tests. Gregory-Hansen Cointegration Test results show that Turkish GDP, tourism revenues and foreign exchange rates are in a cointegrated relationship in the long-run. Moreover, Toda-Yamamoto Causality Test results indicate that tourism revenues and foreign exchange rates are the cause of GDP in Turkey. Consequently, both test results state that TLG hypothesis is valid for Turkey during $1965-2013$ period. Although these results are contradicting with the results of Katircioglu (2009a) which states that TLG hypothesis is not valid for Turkey, they are on the same line with Arslanturk \& Atan(2012), Arslanturk et al.(2011), Husein \& Kara(2011), Gunduz \& Hatemi-J(2005) and Kasman \& Kasman(2004) which are also about Turkish tourism-led growth experience. Furthermore, the empirical evidences state that there exists a structural break in the examined macroeconomic series. Consequently, it's important to take into account structural changes in Turkish economy while analysing the validity of TLG hypothesis in this country.

The findings of this paper are important for policy makers as well as academicians and show that this issue still deserves further attention for Turkey as a country where some structural changes have been experienced since 1960s. The empirical results underlying the validity of TLG hypothesis in Turkey suggest that tourism is an important determinant of overall long-run economic growth in this country. Consequently, a policy implication which may be drawn from this study is that Turkey can improve its growth performance by supporting the contribution of tourism industry. It seems also important that the synchronisation of foreign exchange rate and tourism policies should be provided, since foreign exchange rate, tourism revenues and real GDP are in a cointegrated relationship and also foreign exchange rates and tourism revenues are both cause of real GDP increase in Turkey. Lastly, empirical results suggest that Turkish economy has been affected from structural changes and hence policy makers should revise and update tourism and exchange rate policies in the case of economic crises, if they desire to enhance the effectiveness of their policies.

\section{References}

Albaladejo, I. P., Gonzalez - Martinez, M. I. \& Martinez - Garcia, M. P. (2014). Quality and Endogenous Tourism: An Empirical Approach. Tourism Management. 41, 141 - 147. doi: 10.1016/j.tourman.2013.09.006

Arslanturk, Y., Balcilar, M. \& Ozdemir, Z. A. (2011). Timevarying Linkages between Tourism Receipts and Economic Growth in a Small Open Economy. Economic Modelling, 28, 664 - 671. doi:10.1016/j. econmoc.2010.06.003

Arslanturk, Y. \& Atan, S. (2012). Dynamic Relation between Economic Growth, Foreign Exchange and Tourism Incomes: An Econometric Perspective on Turkey. Journal of Business, Economics \& Finance, 1(1), 30 - 37. Retrieved from: http://dergipark. ulakbim.gov.tr’.

Aslan, A. (2014). Tourism Development and Economic Growth in the Mediterranean Countries: Evidence from Panel Granger Causality Tests. Current Issues in Tourism, 17(4), 363 - 372. doi: $10.1080 / 13683500.2013 .768607$

Balaguer, L. \& Cantavella-Jorda, M. (2002). Tourism as a Long- Run Economic Growth Factor: The Spanish Case. Applied Economics, 34, 877 - 884. doi: $10.180 / 00036840110058923$

Belloumi, M. (2010). The Relationship between Tourism Receipts, Real Effective Exchange Rate and Economic Growth in Tunisia. International Journal of Tourism Research, 12, 550 - 560. doi:10.1002/jtr.774 
Bouzahzah, M. \& El Menyari, Y. (2013). The Relationship between International Tourism and Economic Growth: The Case of Morocco and Tunisia. MPRA. Paper No 44102. Retrieved from: http://mpra. ub.uni-muenchen.de/44102/

Brida, J. G., Carrera, E. J. S. \& Risso, W. A. (2008). Tourism`s Impact on Long-Run Mexican Economic Growth. Economics Bulletin, 3(21), 1 - 8. Retrieved from: http://economicsbulletin.vanderbilt. edu/2008/volume3/EB-07C20155A.pdf

Brida, J. G., Risso, W. A., Lanzilotta, B. \& Lionetti, S. (2010). The Tourism-Led-Growth Hypothesis for Uruguay. Tourism Economics, 16(3), 765 - 771. Retrieved from: http://papers.ssrn.com/sol3/papers. cfm?abstract_id=1333102

Brida, J. G., Bibiana, L., Pereyra, J. S. \& Pizzolon, F. (2013). A Nonlinear Approach to the Tourism-Led Growth Hypothesis: The Case of the MERCOSUR. Current Issues in Tourism, doi:10.1080/13683500.2 013.802765

Caglayan, E., Sak, N. \& Karymshakov, K. (2012). Relationhip between Tourism and Economic Growth: A Panel Granger Causality Approach. Asian Economic and Financial Review, 2(5), 591 - 602. Retrieved from: http://www.aessweb.com/pdf-files/591-602. pdf

Campos, J., Ericsson, N.R. \& Hendry, D.F. (1996). Cointegration Tests in the Presence of Structural Breaks. Journal of Econometrics, 70, 187 - 220. Retrieved from: http://www.sciencedirect.com/science/ article/pii/0304407694016895

Cortes-Jimenez, I. \& Pulina, M. (30 August - 3 September 2006). Tourism and Growth: Evidence for Spain and Italy. 46th Congress of the European Regional Science Association, University of Thessaloniki, Greece.

Demiroz, D. M. \& Ongan, S. (2005). The Contribution of Tourism to the Long-Run Turkish Economic Growth. Journal of Economics, 09, 880 - 894. Retrieved from: http://www.ceeol.com
Ghali, M. A. (1976). Tourism and Economic Growth: An Empirical Study. Economic Development and Cultural Change, 24(3), 527 - 538. Retrieved from: http://www.jstor.org/stable/1153003

Gregory, A.W. \& Hansen, B.E. (1996). Residual-based Tests for Cointegration in Models with Regime Shifts. Journal of Econometrics, 70, 99 - 126. Retrieved from: http://www.sciencedirect.com/science/ article/pii/0304407669416857

Gunduz, L. \& Hatemi - J, A. (2005). Is the Tourismled Growth Hypothesis Valid for Turkey? Applied Economics Letters, 12, 499 - 504. doi: 10.1080/13504850500109865

Hendry, D.F. \& Neale, A.J. (1991). A Monte Carlo Study of the Effects of Structural Breaks on Tests for Unit Roots. Ch. 8 in: P. Hackl \& A.H. Westlund, (Eds.), Economic Structural Change: Analysis and Forecasting. (95 - 119). Springer-Verlag, Berlin.

Husein, J. \& Kara, S. M. (2011). Research Note: Re examining the Tourism-led Growth Hypothesis for Turkey. Tourism Economics, 17(4), 917 - 924. Retrieved from: http://www.ingentaconnect.com/ content/ip/tec/2011/00000017/00000004/art00011

Hye, Q. M. A. \& Khan, R. E. A. (2013). Tourism-led Growth Hypothesis: A Case Study of Pakistan. Asia Pacific Journal of Tourism Research, 18(4), 303 313. doi: $10.1080 / 10941665.2012 .658412$

Kasman, A. \& Kasman, S.K. (2004). Cointegration and Causality between Tourism Revenues and Economic Growth. Iktisat Isletme ve Finans (Economics, Business and Finance), 19(220), 122 - 131. Retrieved from: http://www.iif.com.tr

Katircioglu, S. (2009a). Revisiting the Tourism-LedGrowth Hypothesis for Turkey Using the Bounds Test and Johansen Approach for Cointegration. Tourism Management, 30, 17 - 20. doi:10.1016/j. tourman.2008.04.004

Katircioglu, S. (2009b). Testing the Tourism-Led Growth Hypothesis: The Case of Malta. Acta Oeconomica, 59(3), 331 - 343.doi: 10.1556/AOecon.59.2009.3.4 
Katircioglu, S. (2009c). Tourism, Trade and Growth: The Case of Cyprus. Applied Economics, 41, 2741 2750. doi: 10.1080/00036840701335512

Katircioglu, S. T. (2010). International Tourism, Higher Education and Economic Growth: The Case of North Cyprus. The World Economy, 1955 - 1972, doi:10.1111/j.1467-9701.2010.0.x.

Katircioglu, S. (2010). Research note: Testing the Tourism-led Growth Hypothesis for Singapore an Empirical Investigation from Bounds Test to Cointegration and Granger Causality Tests. Tourism Economics, 16(4), 1095 - 1101. Retrieved from: http://www.ingentaconnect.com/content/ip/ tec/2010/00000016/00000004/art00019

Lionetti, S. \& Gonzalez, O. (2011). On the Relationship between Tourism and Growth in Latin America. Tourism and Hospitality Research, 12(1), 15-24. doi: 10.1177/1467358411429635

MacKinnon, J.G. (1991). Critical Values for Cointegration Tests. Chapter 13 in Long-Run Economic Relationships: Readings in Cointegration". R.F. Engle \& C.W.J. Granger (Eds.). Oxford. Oxford University Press.

McCombie, J.S.L. \& Thirlwall, A.P. (1994). Economic Growth and the Balance-of-Payments Constraint. London: Macmillan Press.

Nissan, E., Galindo, M.-A. \& Mendez, M. T. (2011). Relationship between Tourism and Economic Growth. The Service Industries Journal, 31(10), 1567 - 1572. doi: 10.1080/02642069.2010.485636

Parrilla, J. C., Font, A. R. \& Nadal, J. R. (2007). Tourism and Long-Term Growth: A Spanish Perspective. Annals of Tourism Research, 34(3), 709 - 726. doi: 10.1016/j.annals.2007.02.003

Perron, P. (1997). Further Evidence on Breaking Trend Functions in Macroeconomic Variables. Journal of Econometrics, 80, 355 - 385. Retrieved from: http:// www.sciencedirect.com/science.com/science/article/pii/S0304407697000493
Perron, P. (1989). The Great Crash, the Oil Price Shock and the Unit Root Hypothesis. Econometrica, 57, 1361 - 1401. Retrieved from: http://www.jstor.org/ stable/1913712

Proenca, S. \& Soukiazis, E. (2008). Tourism as an Economic Growth Factor: A Case Study for Southern European Countries. Tourism Economics, 14(4), 791 - 806. Retrieved from: http://www.ingentaconnect. com/content/ip/tec/2008/00000014/00000004/ $\operatorname{art00008}$

Said, S. \& Dickey, D.A. (1984). Testing for Unit Roots in Autoregressive-Moving Average Models of Unknown Order. Biometrika, 71, 599 - 607. doi: 10.1093/biomet/71.3.599

Sequeira, T. N. \& Nunes, P. M. (2008). Does Tourism Influence Economic Growth? A Dynamic Panel Data Approach. Applied Economics, 40(18), 2431 2441. doi: $10.1080 / 00036840600949520$

Srinivasan, P., Santhosh, K.P.K. \& Ganesh, L. (2012). Tourism and Economic Growth in Sri Lanka: An ARDL Bounds Testing Approach. Environment and Urbanization ASIA, 3(2), 397 - 405. doi: 10.1177/0975425312473234

Tang, C. F. \& Tan, E. C. (2013). How Stable is the Tourism-Led Growth Hypothesis in Malaysia? Evidence from Disaggregated Tourism Markets. Tourism Management, 37, 52 - 57. doi: 10.1016/j. tourman.2012.12.014

Tang, C.F. \& Abosedra, S. (2014). Small Sample Evidence on the Tourism-led Growth Hypothesis in Lebanon. Current Issues in Tourism, 17(3), 234 246. doi: 10.1080/13683500.2012.732044

The Central Bank of the Republic of Turkey. Foreign Exchange Database. Retrieved February 15, 2015, from http://www.tcmb.gov.tr

Toda, H.Y. \& Yamamoto, T. (1995). Statistical Inference in Vector Autoregressions with Possibly Integrated Processes. Journal of Econometrics, 66, 225 - 250. Retrieved from: http://www.sciencedirect.com/science/article/pii/0304407694016168\# 
Tugcu, C. T. (2014). Tourism and Economic Growth Revisited: A Panel Causality Analysis for the Case of the Mediterranean Region. Tourism Management, 42, 207 - 212. doi: 10.1016/j.tourman.2013.12.007

The Republic of Turkey Ministry of Culture and Tourism.Tourism Revenues Statistics. Retrieved February 15, 2015, from http://www.kultur.gov.tr.

Turkish Statistical Institute. Annual GDP with Constant Prices. Retrieved February 15, 2015, from http://www.turkstat.gov.tr.

World Travel \& Tourism Council. (2014a). Travel \& Tourism Economic Impact 2014 - Turkey. Retrieved from http://www.wttc.org/focus/research-foraction/economic-impactanalysis/

World Travel \& Tourism Council. (2014b). Travel \& Tourism Economic Impact 2014 - WORLD. Retrieved from http://www.wttc.org/focus/research-foraction/economic-impactanalysis/
Yavuz, N.C. (2006). Turkiye'de Turizm Gelirlerinin Ekonomik Buyumeye Etkisinin Testi: Yapısal Kırılma ve Nedensellik Analizi. Dogus Universty Journal, 7(2), 162 - 171. Retrieved from: openaccess. dogus.edu.tr:8080/xmlui/handle/11376/443

Yeldan, E. \& Boratav, K. (2006). Turkey, 1980 - 2000: Financial Liberalization, Macroeconomic (In)Stability, and Patterns of Distribution. Lance Taylor (Ed.). External Liberalization in Asia, Post-Socialist Europe and Brazil. (417 - 455). Oxford: Oxford University Press.

Zivot, E. \& Andrews, D.W.K. (1992). Further Evidence on the Great Crash, the Oil-Price Shock and the Unit-Root Hypothesis. Journal of Business \& Economic Statistics, 10, 251 - 270. Retrieved from: http://www.jstor.org/stable/1391541 